\title{
INTERFERENTES ENDÓCRINOS NO AMBIENTE
}

\author{
Gislaine Ghiselli e Wilson F. Jardim*
}

Instituto de Química, Universidade Estadual de Campinas, CP 6154, 13081-970 Campinas - SP, Brasil

Recebido em 6/4/06; aceito em 3/7/06; publicado na web em 7/2/07

\begin{abstract}
ENDOCRINE DISRUPTORS IN THE ENVIRONMENT. Although the hypothesis that environmental chemicals may exhibit endocrine disrupting effects is not new, the issue has been a growing level of concern due to reports of increased incidences of endocrine-related disease in humans, including declining male fertility, and more significantly, to adverse physiological effects observed in wildlife where cause and effect relationships are more evident. The list of endocrine disrupting chemicals (EDCs) includes a range of anthropogenic compounds, phytoestrogens, naturally occurring sex steroids and synthetic estrogens. Within the aquatic environment, the presence of EDCs has concerned many scientists and water quality regulators. Discharge of effluents from treatment facilities is likely to be a significant source of input of contaminants to many systems, and the potential for concentration of hydrophilic compounds and transformation products within sludges has implications for their disposal. Then, understanding the processes and the fate of EDCs on the environment, as well as the mechanisms of endocrine disruption, may facilitate controlling or limiting exposure of both humans and the environment to these compounds.
\end{abstract}

Keywords: endocrine disruptors; physicochemical properties; sources.

\section{INTRODUÇÃO}

Os modelos de desenvolvimento adotados pelo homem para a agricultura, a pecuária, a indústria e os centros urbanos não têm levado em conta, há muito tempo, o meio ambiente. Como resultado, diversos problemas ambientais surgem a cada momento, muitos deles praticamente irreversíveis e de extrema relevância. Como exemplo, pode-se citar as consequiências ambientais da expansão do uso de produtos químicos orgânicos sintéticos, com ênfase naquelas substâncias cuja toxicidade chega a afetar a saúde humana, especialmente no que diz respeito ao câncer e aos defeitos congênitos, assim como o bem-estar de organismos inferiores ${ }^{1,2}$.

Ainda que grandes quantidades de produtos químicos sintéticos tivessem sido lançadas no meio ambiente desde 1940, a geração nascida entre 1950 e 1960 foi a primeira a sofrer os efeitos desta exposição, no desenvolvimento intra-uterino, principalmente devido ao estoque disponível destas substâncias no tecido adiposo materno. Como os representantes mais velhos desta geração ainda não haviam adquirido a sua maturidade plena até o final dos anos 70, apenas recentemente foi possível avaliar o impacto, em longo prazo, desta exposição na saúde humana ${ }^{3}$.

Embora já existissem, desde o início do século XX, hipóteses prevendo alterações no funcionamento do sistema endócrino de algumas espécies animais expostas a determinadas substâncias químicas tóxicas, apenas recentemente esta importante questão tem recebido atenção por parte da comunidade científica, principalmente devido ao número crescente de publicações que relatam o aumento da incidência de disfunções no sistema endócrino de seres humanos (incluindo a infertilidade masculina) e, mais significativamente, efeitos fisiológicos adversos observados em espécies animais para as quais a relação causa/efeito é mais evidente. De fato, as evidências observadas em estudos envolvendo moluscos, crustáceos, peixes, répteis, pássaros e alguns mamíferos têm sugerido que possíveis alterações de saúde humana envolvendo o sistema reprodutivo, tais como o câncer de mama e de testículo, podem estar relacionadas à exposição a tais substâncias ${ }^{3-8}$.

*e-mail: wfjardim@iqm.unicamp.br
Uma grande parte da evidência dos possíveis efeitos destas substâncias em seres humanos foi obtida a partir da experiência envolvendo mulheres grávidas que tomaram o estrogênio sintético dietilestilbestrol (DES), prescrito para evitar o aborto espontâneo e promover o crescimento do feto, no período entre 1948 a 1971. Muitas das filhas dessas mulheres são hoje estéreis e, uma minoria, tem desenvolvido um tipo raro de câncer vaginal. Os homens adultos mostram maior incidência de anormalidades em seus órgãos sexuais, apresentam contagem média de espermatozóides diminuída e podem sofrer um risco maior de desenvolver câncer de testículos ${ }^{2,3,6,9}$.

Esta nova ameaça à saúde de espécies animais, incluindo os seres humanos, tem despertado interesse público neste tema, principalmente após a publicação do livro Our Stolen Future (Nosso Futuro Roubado), de Theo Colburn e seus associados, em 1996 ${ }^{2-4}$. Devido à complexidade deste tema, muitas vezes as constatações científicas encontradas na literatura, relatadas quase que exclusivamente em inglês, são polemicamente discutidas entre os pesquisadores, os ambientalistas e as autoridades. Deste modo, este presente artigo tem como principal objetivo divulgar, em âmbito nacional, a problemática atual envolvendo a presença dos interferentes endócrinos no meio ambiente, fornecendo ao leitor, tanto da academia como dos órgãos legisladores e de controle ambiental, informações sobre os mecanismos de ação destas substâncias nos organismos vivos, incluindo uma listagem contendo diversas substâncias classificadas como interferentes endócrinos, suas propriedades físico-químicas mais relevantes, bem como suas principais fontes.

\section{DEFINIÇÕES}

Muitas definições ${ }^{3-6,9-17}$ têm sido propostas para um interferente endócrino. Entretanto, em todas elas existe um ponto em comum: trata-se de uma substância química que pode interferir no funcionamento natural do sistema endócrino de espécies animais, incluindo os seres humanos. Tal substância pode ser de origem antrópica, também denominada xenoestrogênio, ou de origem natural, como por ex., os fitoestrogênios.

Alguns pesquisadores definem um interferente endócrino com base nos seus efeitos, ou seja, trata-se de uma substância química 
que, mesmo presente em concentração extremamente baixa, é capaz de interferir no funcionamento natural do sistema endócrino causando câncer, prejudicando os sistemas reprodutivos (por ex., reduzindo a produção de espermatóides) e causando outros efeitos adversos. Por isso, tais substâncias são mundialmente denominadas "endocrine disruptors" (EDs) ou ainda "endocrine disrupting compounds or chemicals" (EDCs) ${ }^{3-6,9-17}$.

A tradução para a língua portuguesa tem gerado algumas denominações diferentes, uma vez que há poucos grupos de pesquisadores brasileiros trabalhando com esta temática. Podem ser encontradas as seguintes denominações: "perturbadores endócrinos"18, "disruptivos ou disruptores endócrinos"19, "desreguladores endócrinos", "interferentes endócrinos"20, "estrogênios ambientais", dentre outras. Embora a tradução exata para a palavra "disrupt" seja desfazer, perturbar, interromper, decidiu-se adotar o termo "interferentes endócrinos" para se referir às tais substâncias, já que as mesmas interferem ou alteram, de alguma forma, o funcionamento natural do sistema endócrino de espécies animais.

Uma definição mais precisa para um interferente endócrino foi primeiramente proposta em 1996, pela Comunidade Científica Européia, durante a Conferência de Weybridge, no Reino Unido. Tal definição é comumente referida como definição de "Weybridge" 12 , e diz que "an endocrine disrupter is an exogenous substance that causes adverse health effects in an intact organism, or its progeny, consequent to changes in endocrine function" $"$.

Muitas substâncias químicas têm demonstrado potencial para serem classificadas como interferentes endócrinos, embora sejam ainda necessárias novas pesquisas para, de fato, comprovar tais suspeitas. Por este motivo, uma nova definição surgiu para esta classe de substâncias. Um interferente endócrino em potencial trata-se de "a substance that possesses properties that might be expected to lead to endocrine disruption in an intact organism",3,4,12.

Em maio de 1997, a agência de proteção ambiental dos Estados Unidos ("U.S. Environmental Protection Agency - USEPA"), através do seu comitê consultivo responsável pela avaliação e diagnóstico de interferentes endócrinos ("Endocrine Disrupter Screening and Testing Advisory Committee - EDSTAC ${ }^{\natural 4,13}$ ), propôs uma definição mais detalhada que considerava também a ampla diversidade de mecanismos envolvidos nas disfunções do sistema endócrino. O EDSTAC ${ }^{13}$ descreve um interferente endócrino como sendo uma substância ou mistura química exógena que altera uma ou mais funções do sistema endócrino, bem como a sua estrutura, causando efeitos adversos tanto sobre um organismo e sua descendência, como em populações ou subpopulações de organismos, tendo como base estudos científicos, dados, evidências de peso e princípios de precaução ${ }^{3-5,13}$.

Outras definições continuam sendo propostas por várias organizações como o Programa Internacional de Segurança Química ("International Programme on Chemical Safety-IPCS"16), mas trata-se de versões redigidas das definições acima mencionadas ${ }^{3,4,16}$.

Os interferentes endócrinos podem exibir tanto um comportamento estrogênico como androgênico. Estrogênios são esteróides hormonais que regulam e sustentam o desenvolvimento sexual feminino e suas funções reprodutivas. Já os androgênios são esteróides hormonais responsáveis pelo desenvolvimento das características sexuais secundárias masculinas $3,5,21,22$.

De fato, várias substâncias químicas suspeitas de causar alteração no sistema endócrino (listadas por algumas organizações como a USEPA) estão relacionadas com uma série de problemas de saúde humana e animal. Segundo o Comitê Científico de Toxicidade, Ecotoxicidade e Ambiente - CCTEA ${ }^{9}$, há associações envolvendo a presença destas substâncias no organismo humano e o surgimento de algumas doenças como câncer de testículo, de mama e de próstata, a queda da taxa de espermatozóides, deformi- dades dos órgãos reprodutivos, disfunção da tireóide e alterações relacionadas com o sistema neurológico ${ }^{3-5,9,22-26}$.

\section{O SISTEMA ENDÓCRINO}

O sistema endócrino (Figura 1) é constituído por um conjunto de glândulas localizadas em diferentes áreas do corpo, como a tireóide, as gônadas e as glândulas supra-renais, e pelos hormônios por elas sintetizados, tais como a tiroxina, os estrogênios e progestagênios, a testosterona e a adrenalina ${ }^{3-5,9}$.

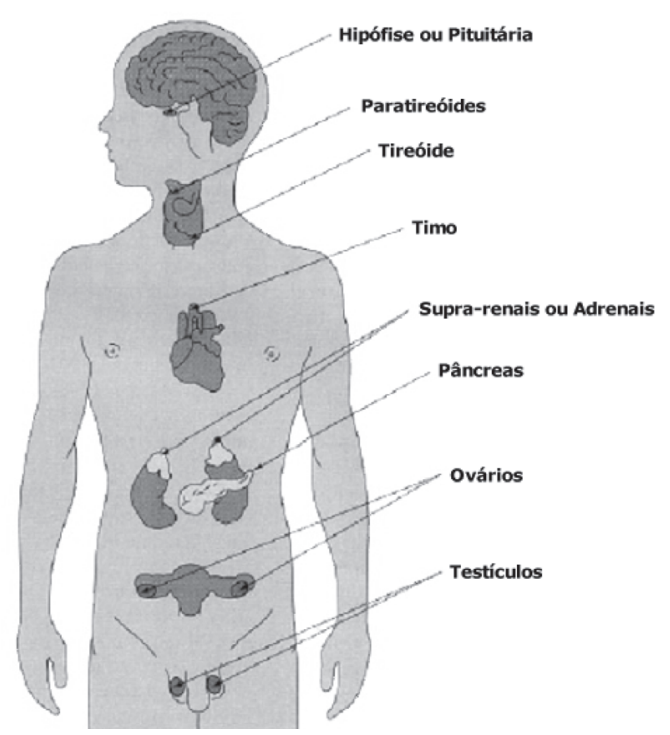

Figura 1. O sistema endócrino

Hormônios são substâncias químicas (mensageiros) produzidas e secretadas pelas glândulas endócrinas e que, lançadas na corrente sangüínea, coordenam o funcionamento do organismo como um todo. Algumas funções que controlam são: atividades de órgãos completos, níveis de sais, açúcares e líquidos no sangue, o uso e armazenamento de energia, o crescimento e o desenvolvimento de um determinado organismo, sua reprodução, suas características sexuais, etc et, $3,21,23,27,28$.

A hipófise ou pituitária é a principal glândula do sistema endócrino, localizada na base do crânio, embaixo do cérebro. Influi direta ou indiretamente na produção e liberação de outros hormônios e está sob controle do sistema nervoso central. É dividida em duas partes: a adeno-hipófise (anterior), que é responsável pela produção de hormônios que regulam as atividades de outras glândulas endócrinas, como o hormônio estimulador do folículo (FSH) e o hormônio luteizante (LH), produzindo também um hormônio responsável pelo crescimento; e a neuro-hipófise (posterior), responsável pela produção do hormônio que controla a reten-

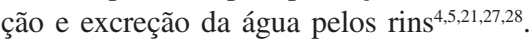

As paratireóides constituem quatro pequenas glândulas localizadas no pescoço, atrás da tireóide. Secretam o hormônio responsável pelo equilíbrio metabólico de cálcio e fósforo no organismo. Já a tireóide está localizada em volta da traquéia, sendo dividida em dois lóbulos. Regula o metabolismo, ou seja, a proporção e a maneira pela qual os alimentos são transformados em energia. É responsável também pela produção de calor corporal e energia muscular, pelo crescimento e desenvolvimento, e pela distribuição e reserva de água e sais no corpo. Secreta os hormônios tiroxina e triiodotironina, que controlam o crescimento e a taxa metabólica, e a calcitonina que canaliza o cálcio no sangue para ser armazenado nos $\operatorname{ossos}^{21,27,28}$. 
O timo é a glândula associada ao sistema linfático, responsável por colher os dejetos da atividade celular, pela distribuição de nutrientes (principalmente gorduras), e pelo transporte dos glóbulos brancos (leucócitos). Ajuda a "treinar" os glóbulos brancos na luta contra as infecções, através do reconhecimento dos germes e outros invasores do corpo ${ }^{21,27,28}$.

As supra-renais ou adrenais são as glândulas localizadas acima dos rins. São divididas em duas camadas distintas: medula (parte interna) e córtex (parte externa). A medula é responsável por secretar, na corrente sangüínea, os hormônios adrenalina e noradrenalina. Também prepara o corpo para a ação em uma situação de perigo ou estresse. O córtex é o responsável pela produção de hormônios corticóides como a aldosterona, que mantém o equilíbrio de água e sais nos rins (íons $\mathrm{K}+\mathrm{e} \mathrm{Na}+$ ), os glucocorticóides, que aceleram o metabolismo e atuam no armazenamento dos açúcares, proteínas e gorduras, e também auxilia a produção de hormônios sexuais ${ }^{21,27,28}$.

O pâncreas atua tanto como uma glândula exócrina quanto endócrina. Como glândula exócrina produz vários sucos digestivos, ricos em enzimas, que passam do canal pancreático para o intestino delgado e atuam na digestão dos alimentos. Como glândula endócrina produz hormônios que fluem diretamente para a corrente sangüínea. $\mathrm{O}$ pâncreas é pontilhado por pequenos aglomerados de células (ilhotas de Langerhans) que secretam dois tipos de hormônios: a insulina e o glucagon. O equilíbrio entre estes dois hormônios é que controla o nível de glicose no sangue ${ }^{21,27,28}$.

Os testículos são os responsáveis pela produção de espermatozóides e androgênios, os hormônios sexuais masculinos. Os espermatozóides são produzidos durante toda a vida e, quando não são liberados, morrem e são reabsorvidos pelo organismo. A formação dos espermatozóides é controlada pelo hormônio estimulador do folículo (FSH), hormônio luteizante ( $\mathrm{LH})$ e pela testosterona, principal androgênio. Ela é responsável pelo desenvolvimento do orgão reprodutor masculino, desde a gestação, além de aumentar a síntese de proteínas, especialmente nos músculos, e contribuir com as funções anabólicas 4,21,27,28. $^{4}$.

Os ovários são responsáveis por produzir e expelir o óvulo, após o seu amadurecimento. Também produzem os hormônios sexuais, regulam a ovulação e a menstruação, garantem a manutenção da gravidez e são os responsáveis pelo desenvolvimento dos caracteres femininos, influenciando no crescimento dos orgãos reprodutivos. O ciclo menstrual é controlado por quatro hormônios: o hormônio estimulador do folículo (FSH), o hormônio luteizante (LH), os estrogênios (como o estradiol, que estimula o desenvolvimento do endométrio e influencia a libido) e a progesterona, essencial para o desenvolvimento do embrião (placenta e glândulas mamárias) 4,21,27,28. $^{\text {. }}$

\section{MECANISMOS DE AÇÃO DOS INTERFERENTES ENDÓCRINOS}

A ação de um determinado hormônio inicia-se através da sua ligação a um receptor específico, no interior de uma célula. O complexo resultante liga-se a regiões específicas do DNA presente no núcleo da célula, o que determina a ação dos genes. Certas substâncias químicas podem também se ligar ao receptor hormonal e, conseqüentemente, mimetizar ou bloquear a ação do próprio hormônio ${ }^{2-4,9,24}$.

Após complexos processos bioquímicos em cadeia, o hipotálamo secreta hormônios que controlam a liberação de outros hormônios pela glândula pituitária. Estas glicoproteínas (também denominadas glandotrofinas) por sua vez, induzem a síntese e a atividade de hormônios de tecidos específicos presentes nas glândulas internas. Os hormônios produzidos nestas glândulas são transportados, pela corrente sangüínea, até tecidos-alvo, iniciando uma mudança na atividade celular nos seus receptores. Esta mudança de atividade é trans- mitida por vários caminhos, através da membrana plasmática, dependendo do tipo de homônio. Estes diferentes processos fisiológicos (em cascata e independentes) são controlados por mecanismos complexos como os de "feedback", que são ativados ou desativados de acordo com os níveis de hormônios encontrados no organismo. Por exemplo, quando a concentração de um determinado hormônio no organismo é elevada, o caminho que leva a sua produção é conseqüentemente desativado. Embora muitos destes caminhos possam ser influenciados por estimulações externas ao organismo, a grande maioria dos distúrbios endócrinos observados e explicados até o momento é atribuída ao funcionamento das gônadas, responsáveis pelas características sexuais secundárias e pelo desenvolvimento e funcionamento dos órgãos sexuais ${ }^{2-5,9,24}$.

Um receptor hormonal possui elevada sensibilidade e afinidade por um hormônio específico, produzido no organismo. Por isso, concentrações extremamente baixas de um determinado hormônio geram um efeito, produzindo uma resposta natural (Figura 2a). Entretanto, estes receptores hormonais também podem se ligar a outras substâncias químicas. Isso explica o porquê de determinados interferentes endócrinos presentes no organismo, mesmo em baixíssimas concentrações, serem capazes de gerar um efeito, provocando conseqüentemente uma resposta ${ }^{3,4}$.
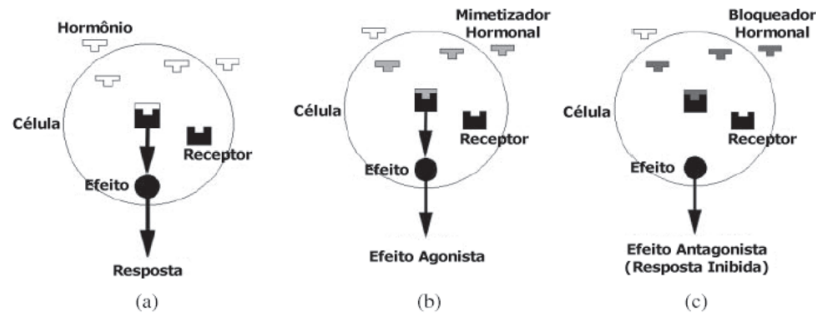

Figura 2. Disfunções endócrinas: a) resposta natural, b) efeito agonista, c) efeito antagonista

A alteração no sistema endócrino ocorre quando o interferente endócrino interage com os receptores hormonais, modificando a sua resposta natural. Dois processos distintos podem ser desencadeados (Figuras $2 \mathrm{~b}$ e 2c). A substância química pode se ligar ao receptor hormonal e produzir uma resposta, atuando então como um mimetizador, ou seja, imitando a ação de um determinado hormônio. Este processo é denominado de efeito agonista (Figura 2b). Se a substância química se ligar ao receptor mas nenhuma resposta for produzida, ela estará agindo como um bloqueador, ou seja, estará impedindo a interação entre um hormônio natural e seu respectivo receptor. Este processo é denominado de efeito antagonista ${ }^{3,4}$ (Figura 2c).

Outros efeitos que podem ocorrer no sistema endócrino são alterações na síntese e na remoção dos hormônios de seus respectivos receptores e, ainda, interações com sistemas multi-hormonais. Como se pode perceber, os processos aqui envolvidos são complexos e por este motivo ainda não foram completamente elucidados ${ }^{3,4}$.

Muitos interferentes endócrinos competem com o estradiol (hormônio sexual feminino produzido naturalmente pelo organismo) pelos receptores de estrogênio. Outros competem com a diidrotestosterona (hormônio sexual masculino produzido naturalmente pelo organismo) pelos receptores de androgênio. Portanto, estas substâncias exercem efeitos de feminização ou masculinização sobre o sistema endócrino. Substâncias que produzem efeitos de feminização são conhecidas como estrogênicas, enquanto que as que produzem efeitos de masculinização são conhecidas como androgênicas. Portanto, se uma substância é considerada antiandrogênica como a flutamida, ela certamente inibirá a ação bioló- 
gica dos androgênios, ligando-se e, conseqüentemente, inativando os receptores de androgênios presentes nos tecidos-alvo. Já uma substância anti-estrogênica, como o tamoxifeno, inibe a ação biológica dos estrogênios ligando-se e, conseqüentemente, inativando os receptores de estrogênios presentes nos tecidos-alvo ${ }^{3-5}$.

Em suma, os interferentes endócrinos podem interferir no funcionamento do sistema endócrino pelo menos de três formas possíveis: imitando a ação de um hormônio produzido naturalmente pelo organismo, como o estrogênio ou a testosterona, desencadeando deste modo reações químicas semelhantes no corpo; bloqueando os receptores nas células que recebem os hormônios, impedindo assim a ação dos hormônios naturais; ou afetando a síntese, o transporte, o metabolismo e a excreção dos hormônios, alterando as concentrações dos hormônios naturais ${ }^{2-5,9,24}$.

\section{PROPRIEDADES FÍSICO-QUÍMICAS MAIS RELEVANTES}

O destino e o comportamento dos interferentes endócrinos, tanto no organismo como no meio ambiente, estão diretamente relacionados com suas propriedades físico-químicas. Portanto, para que se possa compreender os efeitos destas substâncias no meio ambiente, suas propriedades físico-químicas necessariamente devem ser usadas como ferramentas durante os estudos.

\section{Solubilidade em água}

A solubilidade em água $\left(\gamma_{\text {sat }}\right)$ é definida como sendo a concentração máxima de uma substância dissolvida em água pura, a uma dada temperatura. Nas águas superficiais, a solubilidade é fortemente dependente da temperatura, do $\mathrm{pH}$, dos sais dissolvidos ou ainda da existência de substâncias húmicas ou materiais suspensos. Todavia, os valores experimentais são também úteis para se determinar o grau de hidrofobicidade $\left(K_{\text {ow }}\right)$ de uma determinada substância-4,29,31.

Para substâncias gasosas ou que apresentam elevada volatilidade, a solubilidade em água é definida pela lei de Henry, que descreve uma relação linear entre a atividade de uma espécie volátil na fase aquosa e sua atividade na fase gasosa. Ou seja, a solubilidade de um gás em um líquido é proporcional à pressão parcial deste gás, quando em contato com o líquido ${ }^{29-31}$.

\section{Coeficiente de partição}

Partição é a distribuição de uma substância química entre duas fases, seja ela abiótica como água, sedimentos suspensos ou de fundo, ou biótica como plantas e animais, que estão em equilíbrio ou estado estacionário. É expressa pela razão da concentração da substância química nas duas fases avaliadas ${ }^{30,31}$.

\section{Hidrofobicidade}

O grau de hidrofobicidade de uma substância é representado pelo coeficiente de partição octanol/água $\left(K_{\text {ow }}\right)$, ou seja:

$K_{\text {ow }}=\mathrm{C}_{\text {octanol }} / \mathrm{C}_{\text {agua }}$

onde: $\mathrm{C}_{\text {octanol }}$ é a concentração da substância em n-octanol e $\mathrm{C}_{\text {agua }}$ é a concentração da substância em água.

O n-octanol é empregado uma vez que apresenta tanto características hidrofóbicas como hidrofílicas. Portanto, uma ampla faixa de substâncias apresenta valores mensuráveis de $K_{\mathrm{ow}}$. Também serve como modelo para simular os tecidos adiposos (gorduras) encontrados em espécies animais, podendo ser usado para estimar a partição de uma substância em fases orgânicas apolares (outros solventes ou biota) 2,30,31.

O coeficiente de partição octanol/água, por uma questão de conveniência, é geralmente utilizado em sua forma logarítmica decimal (log $K_{\text {ow }}$ ), dado sua magnitude ser, na maioria das vezes, muito grande, excedendo em algumas ocasiões a um milhão. Também é considerado um excelente parâmetro para inferir o fator de bioconcentração de uma determinada substância química ${ }^{2,30,31}$.

A polaridade de uma substância química também está inversamente relacionada com sua hidrofobicidade. A ausência de grupos polares nas moléculas de uma substância altera a polaridade da mesma diminuindo, conseqüentemente, sua solubilidade em água. Deste modo, pode-se dizer que tal substância apresenta elevada hidrofobicidade e elevada lipofilicidade. É o caso, por ex., das substâncias organocloradas ${ }^{30,31}$.

O peso molecular também tem relação com a hidrofobicidade de uma substância. Moléculas com alto peso molecular tendem a apresentar menor solubilidade em água. Portanto, a sua hidrofobicidade é relativamente elevada ${ }^{30,31}$.

\section{Biomagnificação}

O fenômeno da biomagnificação resulta, essencialmente, de uma sequiência de etapas de bioacumulação que ocorrem ao longo da cadeia alimentar. Bioacumulação é um termo geral que descreve a tomada de um contaminante químico, do ambiente, por uma ou todas as rotas possíveis (respiração, dieta, via dérmica, etc.), a partir de qualquer fonte no ambiente onde tais substâncias estão presentes. Por exemplo, os peixes assimilam algumas substâncias químicas procedentes de sua alimentação, ou ainda através da ingestão de material particulado adsorvido nos sedimentos ou presente em suspensão nas águas. Em muitos casos, tais substâncias não são metabolizadas pelo peixe, ou seja, acabam se acumulando nos tecidos adiposos, nos quais sua concentração aumenta com o tempo. Aves predadoras que se alimentam destes peixes, por conseqüência, apresentarão concentrações ainda maiores destas substâncias no organismo ${ }^{2,30,31}$.

\section{Coeficiente de adsorção}

A sorção de substâncias químicas (contaminantes) está diretamente relacionada com o transporte e a mobilidade das mesmas no meio ambiente. Geralmente, moléculas que estão sorvidas apresentam menor mobilidade e, conseqüentemente, acabam não ficando disponíveis para participar de processos de transferência de fases. Também estão menos biodisponíveis e mais protegidas da luz ultravioleta, ocasionando menor degradação das mesmas no ambiente, através da fotólise direta. Substâncias químicas sorvidas não reagem com foto-oxidantes indiretos como os radicais hidroxilas, muitas vezes gerados nos ambientes aquáticos ${ }^{30}$.

$\mathrm{O}$ coeficiente de adsorção $\left(\mathrm{K}_{\mathrm{oc}}\right)$ é bastante útil para descrever a adsorção de uma determinada substância química no material em suspensão (matéria orgânica) presente nas águas superficiais. Este parâmetro aumenta com o aumento da hidrofobicidade de uma substância, isto é, quanto maior o valor de $\mathrm{K}_{\mathrm{ow}}$, maior será a hidrofobicidade e maior será a afinidade da substância pela matéria orgânica ${ }^{4,30,31}$.

\section{Toxicidade}

A toxicologia é o estudo dos efeitos nocivos de substâncias sobre os seres vivos. As substâncias de interesse incluem tanto os produtos químicos sintéticos quanto aqueles naturalmente presentes no ambiente. Na toxicologia, os efeitos são determinados, em geral, pela injeção ou pela administração oral da substância de interesse em animais, observando-se como a saúde dos mesmos pode ser afetada ${ }^{2,32}$. 
Dados toxicológicos relacionados à nocividade de uma substância para um organismo, como um pesticida organoclorado ou um metal pesado, são coletados mais facilmente determinando-se sua toxicidade aguda, que é o início rápido de sintomas (incluindo a morte no limite extremo) que se seguem à absorção de uma dose da substância. Embora a toxicidade aguda de uma substância seja de grande interesse quando ocorre, acidentalmente, uma exposição acentuada à mesma, na toxicologia ambiental a maior preocupação se dá mediante exposições, em longo prazo, a doses individuais relativamente baixas de uma determinada substância tóxica presente no meio ambiente. Trata-se da toxicidade crônica. De modo geral, quaisquer efeitos como, por ex., câncer ou defeitos congênitos decorrentes destas exposições contínuas são também de longa duração e, portanto, classificados como crônicos ${ }^{2,29,32}$.

Ainda que recentemente alguns estudos toxicológicos tenham sido desenvolvidos a partir de testes envolvendo certas bactérias, a maior parte da informação relativa à toxicidade das substâncias químicas é obtida a partir de experimentos efetuados mediante a administração de doses aos animais. A dose da substância administrada nos testes de toxicidade é normalmente expressa em massa por unidade de peso corporal do animal testado ${ }^{2,29,32}$.

Os indivíduos diferem significativamente quanto à sua susceptibilidade a uma dada substância química - alguns respondem à substância mesmo em doses muito baixas, enquanto que outros requerem uma dose muito mais elevada para reagirem. Por esta razão, os toxicologistas criaram as relações dose-resposta. Na maioria das vezes o efeito "resposta" buscado nos testes com animais para construir as curvas dose-resposta é a morte $2,5,29,31,32$.

Em síntese, a toxicidade é uma resposta biológica adversa induzida pela presença de uma ou mais substâncias químicas e/ou de seus metabólitos. Deve-se enfatizar que, a simples presença ou acumulação de uma ou mais substâncias químicas em um determinado organismo não corresponde necessariamente a um efeito biológico adverso. Somente uma resposta biológica induzida pela presença de uma ou mais substâncias químicas e/ou de seus metabólitos, é referenciada como um efeito biológico adverso em potencial. Portanto, uma vez que o tipo e a natureza da resposta biológica e o potencial para induzir tal resposta variam de acordo com os organismos e as substâncias químicas, o julgamento sobre os efeitos biológicos adversos tem de ser, obrigatoriamente, realizado com base nas relações dose-resposta, ao invés de simplesmente ser baseado na magnitude da acumulação ${ }^{31}$.

\section{PRINCIPAIS FONTES DOS INTERFERENTES ENDÓCRINOS}

Tanto os interferentes endócrinos como outras classes de poluentes ambientais apresentam uma variedade de fontes ${ }^{2-4,6,18,33-48}$. Todavia, tais fontes podem ser classificadas em dois grandes grupos: pontuais e não pontuais (ou difusas). As fontes pontuais apresentam um ponto de entrada no meio ambiente bem caracterizado, geralmente através dos cursos d'água. Como exemplo, pode-se citar as descargas de efluentes industriais e esgotos domésticos, derramamentos acidentais, atividades de mineração, enchentes, dentre outras. Trata-se de descargas diretas para os corpos d'água ${ }^{3}$.

Por outro lado, as fontes não pontuais são definidas como fontes que não apresentam um ponto de entrada no meio ambiente bem caracterizado. Bons exemplos destas fontes são as deposições atmosféricas e os escoamentos superficiais, sobretudo provenientes das práticas agrícolas. Trata-se de rotas resultando em deposições parciais dos poluentes antes destes atingirem os corpos d'água ${ }^{3}$.

A questão central é que fontes não pontuais são mais difíceis de serem controladas uma vez que o ponto de entrada dos poluentes no ambiente depende do tipo da fonte, da sua localização e, ainda, da combinação de uma série de processos envolvendo a concentração do poluente, sua distribuição no meio ambiente, suas propriedades físico-químicas e as condições ambientais ${ }^{3}$.

$\mathrm{O}$ transporte de um determinado poluente oriundo de uma fonte não pontual de uma área urbana também parece ser diferente daquele proveniente de uma zona rural. Existem algumas razões para isso: boa parte da área urbana é coberta com materiais impermeáveis; como na área urbana há pouca exposição do solo ao meio ambiente, o processo de erosão é menos favorecido e as partículas do solo acabam sendo transportadas preferencialmente para as águas superficiais; na área urbana a poluição pode se dar também pelo acúmulo de lixos, durante o trânsito, nas emissões radioativas, enquanto que na área rural a poluição advém basicamente da erosão do solo; na área urbana a maioria dos poluentes depositados na superfície do solo (impermeável) acaba sendo escoada para os corpos d'água (lixiviação), enquanto que na área rural as deposições podem ser incorporadas ao solo, ou seja, sorvidas ou infiltradas, dificultando a remoção ${ }^{3}$.

Para os seres humanos a mais importante fonte de contaminação dos interferentes endócrinos é a alimentação, uma vez que muitas destas substâncias são utilizadas durante a produção de alimentos industrializados e/ou no processo de embalagem dos mesmos, ou ainda através da ingestão de água potável contaminada, pois várias destas substâncias não são totalmente destruídas ou degradadas durante o processo empregado nas estações de tratamento, tanto de água como de esgoto ${ }^{3,4,6,10,38}$.

\section{SUBSTÂNCIAS CLASSIFICADAS COMO INTERFERENTES ENDÓCRINOS}

Muitos dos interferentes endócrinos estão também classificados em uma série de grupos de compostos orgânicos potencialmente tóxicos, tais como micropoluentes orgânicos, substâncias tóxicas persistentes (STP), poluentes orgânicos persistentes (POP), poluentes emergentes, dentre outros ${ }^{2,48-50}$.

Entretanto, existem basicamente duas classes de substâncias que podem alterar o funcionamento do sistema endócrino: os hormônios naturais que incluem estrogênio, progesterona e testosterona, presentes no corpo humano e nos animais, e os fitoestrogênios, substâncias contidas em algumas plantas, como nas sementes de soja, e que apresentam uma atividade semelhante aos esteróides hormonais quando ingeridas por um determinado organismo; e as substâncias sintéticas que incluem os hormônios sintéticos (hormônios idênticos aos naturais, fabricados pelo homem e utilizados como contraceptivos orais e/ou aditivos na alimentação animal), bem como os xenoestrogênios, substâncias produzidas para utilização nas indústrias, na agricultura e para os bens de consumo. Estão incluídos nesta categoria os pesticidas e aditivos plásticos, as bifenilas policloradas, os hidrocarbonetos policíclicos aromáticos, compostos de organoestanho, alquilfenóis, e ainda subprodutos de processos industriais, como as dioxinas e furanos ${ }^{2-4,6,9,10,23,24}$.

Os interferentes endócrinos ainda podem ser classificados, segundo sua ação biológica, em agonista ou antagonista, termos estes mais genéricos. Conforme já mencionado, uma substância exibe um comportamento agonista quando mimetiza um determinado hormônio (são as substâncias estrogênicas ou androgênicas). Quando determinada substância bloqueia um hormônio, ligando-se ao seu receptor, diz-se que ela exibe um comportamento antagonista. Estas são as substâncias anti-estrogênicas ou anti-androgênicas ${ }^{3,4}$.

Várias substâncias químicas classificadas por diversas organizações mundiais como interferentes endócrinos (ou interferentes endócrinos potenciais) são listadas na Tabela 1. A União Européia também elaborou um relatório contendo uma vasta lista de subs- 
tâncias suspeitas de interferir no sistema endócrino, tanto de seres humanos como de diferentes espécies animais, com base em seus estudos. Foram identificadas 118 substâncias, sendo 12 destas designadas prioritárias para a condução de estudos mais detalhados. São elas: dissulfeto de carbono, orto-fenilfenol, difenil éter tetrabromado, 4-cloro-3-metilfenol, 2,4-diclorofenol, resorcinol, 4nitrotolueno, 4-octilfenol, estrona, estradiol, etinilestradiol e 2,2'bis(4-(2,3-epoxipropoxi)fenil)propano ${ }^{3}$.

Até o momento, a maioria das substâncias classificadas como interferentes endócrinos são pesticidas. Alguns metais, como cádmio e mercúrio, também apresentaram atividade semelhante no sistema endócrino, especialmente nas suas formas orgânicas (por ex., metilmercúrio ${ }^{51}$ ). Porém, neste artigo é focado um grupo específico de substâncias classificadas como interferentes endócrinos: os esteróides e fitoesteróides, os surfactantes, os pesticidas, herbicidas e fungicidas (relatados coletivamente como pesticidas), os compostos poliaromáticos, os compostos orgânicos contendo oxigênio e os compostos de organoestanho.

\section{Esteróides Sexuais}

Esteróides compreendem um grupo de substâncias, tais como os hormônios e seus precursores, freqüentemente determinado em materiais biológicos como sangue e urina. De acordo com suas funções, podem ser divididos em três principais classes: esteróides hormonais, como os androgênios, corticóides, estrogênios e progestagênios; colesterol e derivados; e fitoesteróides ${ }^{2-4,21,23,27,32,52,53}$.

Os androgênios são esteróides que contêm em sua estrutura dezenove átomos de carbono (C19), distribuídos de forma cíclica e cuja substância mais característica é a testosterona, principal hormônio sexual masculino. Os corticóides são produzidos nas glândulas supra-renais, na parte externa denominada córtex, cujos principais representantes são os glucocorticóides e a aldosterona, que tem como principal função regular o metabolismo dos íons potássio e sódio nos rins ${ }^{3,4,21,27}$.

Os estrogênios apresentam em sua estrutura um grupo fenólico e em alguns casos um grupo hidroxila alifático, enquanto que nos

Tabela 1. Lista de substâncias classificadas como interferentes endócrinos por várias organizações

\begin{tabular}{|c|c|c|c|c|c|}
\hline \multirow[t]{2}{*}{ SUBSTÂNCIAS } & UKEA & USEPA & OSPAR & \multirow[t]{2}{*}{ JEA } & \multirow[t]{2}{*}{ WWF } \\
\hline & & & in vivo in vitro & & \\
\hline
\end{tabular}

\section{Esteróides}

Etinilestradiol

$17 \beta$-Estradiol

Estrona

Mestranol

Dietilestilbestrol

Alquilfenóis

Nonilfenol

Nonilfenol Etoxilado

Octilfenol

Octilfenol Etoxilado

Compostos Poliaromáticos

Bifenilas Policloradas

Retardantes de Chama

Hidrocarbonetos Policíclicos Aromáticos (PAH)

Compostos com Oxigênio

Ftalatos

Pesticidas

Atrazina

Simazina

Diclorvos

Endossulfan

Trifluralina

Demeton-S-metil

Dimetoato

Linuron

Permetrina

Lindano

Clordano

Dieldrin

Hexaclorobenzeno

Pentaclorofenol

\section{Outros}

Dioxinas e Furanos Tributilestanho
Bisfenol A

\begin{tabular}{|c|c|c|c|c|c|}
\hline $\mathrm{X}$ & & $\mathrm{X}$ & & & \\
\hline $\mathrm{X}$ & & X & & & \\
\hline $\mathrm{x}$ & & $\mathrm{X}$ & & & \\
\hline $\mathrm{X}$ & & X & & & \\
\hline $\mathrm{X}$ & & $\mathrm{X}$ & & & \\
\hline $\mathrm{X}$ & $\mathrm{x}$ & $\mathrm{X}$ & & $\mathrm{x}$ & $\mathrm{x}$ \\
\hline $\mathrm{X}$ & & & $\mathrm{X}$ & & \\
\hline $\mathrm{x}$ & $\mathrm{X}$ & X & & $\mathrm{x}$ & \\
\hline $\mathrm{X}$ & & & & & \\
\hline $\mathrm{X}$ & $\mathrm{X}$ & $\mathrm{X}$ & & $\mathrm{x}$ & $\mathrm{X}$ \\
\hline & & & $\mathrm{X}$ & $\mathrm{x}$ & $\mathrm{x}$ \\
\hline & $\mathrm{X}$ & & $X$ & & \\
\hline $\mathrm{x}$ & $\mathrm{X}$ & & $\mathrm{X}$ & $\mathrm{X}$ & $\mathrm{X}$ \\
\hline $\mathrm{X}$ & $\mathrm{X}$ & & & $\mathrm{X}$ & $\mathrm{X}$ \\
\hline $\mathrm{X}$ & $\mathrm{X}$ & & $\mathrm{X}$ & $\mathrm{X}$ & $\mathrm{X}$ \\
\hline $\mathrm{X}$ & $\mathrm{X}$ & & $\mathrm{X}$ & $\mathrm{x}$ & $\mathrm{X}$ \\
\hline $\mathrm{X}$ & & & & & \\
\hline $\mathrm{X}$ & $\mathrm{X}$ & & $\mathrm{X}$ & $\mathrm{x}$ & $\mathrm{X}$ \\
\hline $\mathrm{x}$ & $\mathrm{X}$ & & & & $\mathrm{X}$ \\
\hline X & & & & & \\
\hline $\mathrm{X}$ & & & & & $\mathrm{X}$ \\
\hline & & & & & $\mathrm{X}$ \\
\hline $\mathrm{x}$ & $\mathrm{X}$ & & & $\mathrm{X}$ & \\
\hline $\mathrm{x}$ & $\mathrm{X}$ & X & & & $\mathrm{X}$ \\
\hline $\mathrm{x}$ & & & $\mathrm{x}$ & $\mathrm{x}$ & $\mathrm{x}$ \\
\hline $\mathrm{x}$ & $\mathrm{X}$ & & $\mathrm{X}$ & $\mathrm{X}$ & $\mathrm{X}$ \\
\hline $\mathrm{x}$ & & & $\mathrm{X}$ & $\mathrm{x}$ & $\mathrm{x}$ \\
\hline $\mathrm{X}$ & $\mathrm{X}$ & & & $\mathrm{X}$ & $\mathrm{X}$ \\
\hline $\mathrm{X}$ & & $X$ & & $\mathrm{X}$ & $\mathrm{X}$ \\
\hline $\mathrm{X}$ & $\mathrm{X}$ & $\mathrm{X}$ & & X & $\mathrm{X}$ \\
\hline
\end{tabular}

UKEA: Agência Ambiental do Reino Unido; USEPA: Agência de Proteção Ambiental dos Estados Unidos;

OSPAR: Comissão de Paris e Oslo; JEA: Agência Ambiental do Japão; WWF: Organização não Governamental 
progestagênios este grupo fenólico é substituído por um grupo cetona. Como são os principais responsáveis pelo crescimento e pela reprodução de espécies animais, incluindo os seres humanos, seus derivados sintéticos são bastante empregados como contraceptivos (hormônios inibidores do processo de ovulação), ao passo que os estrogênios são também administrados no controle dos sintomas que envolvem a menopausa, distúrbios fisiológicos e no tratamento do câncer de próstata e de mama. Já os progestagênios são empregados nos tratamentos voltados para as causas de infertilidade e descontrole do ciclo menstrual. Em geral, são rapidamente absorvidos pelo organismo e, então, metabolizados no fígado $3,4,21,23,27,52$.

Ainda existem os esteróides anabólicos ou anabolizantes sintéticos que nada mais são que substâncias químicas relacionadas estruturalmente com a testosterona. A testosterona pode ser aromatizada a estradiol, sendo esta a principal via de biossíntese de estrogênios em homens e mulheres após a menopausa. A aplicação terapêutica mais evidente que os androgênios possuem é a de suprir a deficiência da função endócrina dos testículos e aumentar a síntese protéica do organismo. Para obter esses efeitos os ésteres da testosterona são preferidos à sua forma livre, podendo ser aplicados por via intramuscular. Foram feitas muitas alterações na molécula da testosterona para diminuir seus efeitos androgênicos e manter ou aumentar os efeitos anabolizantes. Por exemplo, a remoção do grupamento metila em C19 aumenta o efeito anabólico e diminui a ação androgênica, caso da 19-nortestosterona ${ }^{21,32}$.

Os esteróides sintéticos são basicamente obtidos a partir de reações de alquilação (principalmente grupos metila e etila) ou esterificação dos hormônios naturais, prevenindo-os da metabolização rápida quando no organismo, garantindo assim o efeito desejado. Os esteróides sintéticos mais utilizados são o etinilestradiol e mestranol (estrogênios), norgestrel e noretisterona (progestagênicos), metiltestosterona, fluoximesterona, etilestrenol, mesterolona, fenilpropionato de nandrolona (Durabolin ${ }^{\circledR}$ ) e ésteres da testosterona, como anabolizantes $3,4,21,32$.

Estrogênios, androgênios e progestagênios, tanto naturais quanto sintéticos, são excretados principalmente pela urina, na forma biologicamente inativa, ou seja, como conjugados solúveis em água (principalmente glucoronídios ou sulfatos) e em menor proporção pelas fezes (na forma livre), apresentando variações com relação à solubilidade em água, taxa de excreção e catabolismo biológico. Sob condições ambientais estes conjugados são rapidamente hidrolisados, levando aos hormônios livres e seus metabólitos ${ }^{3,4,21,27,52}$.

Vários organismos excretam diferentes quantidades de esteróides sexuais (hormônios), dependendo da idade, do estado de saúde, da dieta ou gravidez. Apenas como curiosidade, a quantidade de estrogênio excretada por uma mulher grávida pode ser até mil vezes maior que a de uma mulher em atividade normal (da ordem de 2 a $20 \mu \mathrm{g}$ estrona/dia, 3 a $65 \mu \mathrm{g}$ estriol/dia, e 0,3 a $5 \mu \mathrm{g}$ estradiol/dia), dependendo do estágio da gravidez ${ }^{4}$.

Shore et al..$^{54}$ foram um dos primeiros pesquisadores que investigaram a influência e a concentração dos esteróides sexuais como poluentes ambientais. Posteriormente, vários estudos foram realizados com o objetivo de determinar as concentrações dos hormônios sexuais em diversas matrizes ambientais, identificando suas possíveis fontes. Um destes estudos, realizado nos EUA, mostrou que na água de 10 riachos avaliados, $40 \%$ deles apresentavam concentração de testosterona acima de 1,0 ng/L. Dentre estas áreas, três estavam localizadas em regiões que empregavam como fertilizante, altas quantidades de adubo animal (frango) enquanto que apenas uma havia recebido esgoto doméstico. Amostras de esgoto doméstico (bruto e tratado), provenientes de uma estação de tratamento, também apresentaram elevados teores de hormônios naturais: $19-273 \mathrm{ng} / \mathrm{L}$ para testosterona e $49-73 \mathrm{ng} / \mathrm{L}$ para estrogênios no esgoto bruto e 1,6-7,2 ng/L para testosterona e 0,8 a $4,0 \mathrm{ng} / \mathrm{L}$ para estrogênios no esgoto tratado. Assim, as duas principais fontes de esteróides sexuais, naturais e sintéticos, estão localizadas nas áreas rurais destinadas à agropecuária, através da contaminação do solo e da água pelos dejetos animais, como o estrume de gado, bem como na área urbana, através de descargas de esgotos domésticos nas águas superficiais ${ }^{4}$.

Na Figura 3 são ilustradas as fórmulas estruturais dos principais esteróides mencionados. A Tabela 2 fornece algumas propriedades físico-químicas, ocorrência e utilização dos esteróides aqui abordados. Apenas para o etinilestradiol foi encontrado um valor que estimasse sua toxicidade aguda. $\mathrm{O} \mathrm{LD}_{50}$, via oral em camundongos, equivale a $1737 \mathrm{mg} / \mathrm{kg}^{55}$. Os compostos estradiol, estriol, progesterona e etinilestradiol são classificados como sendo potencialmente cancerígenos ${ }^{27}$.

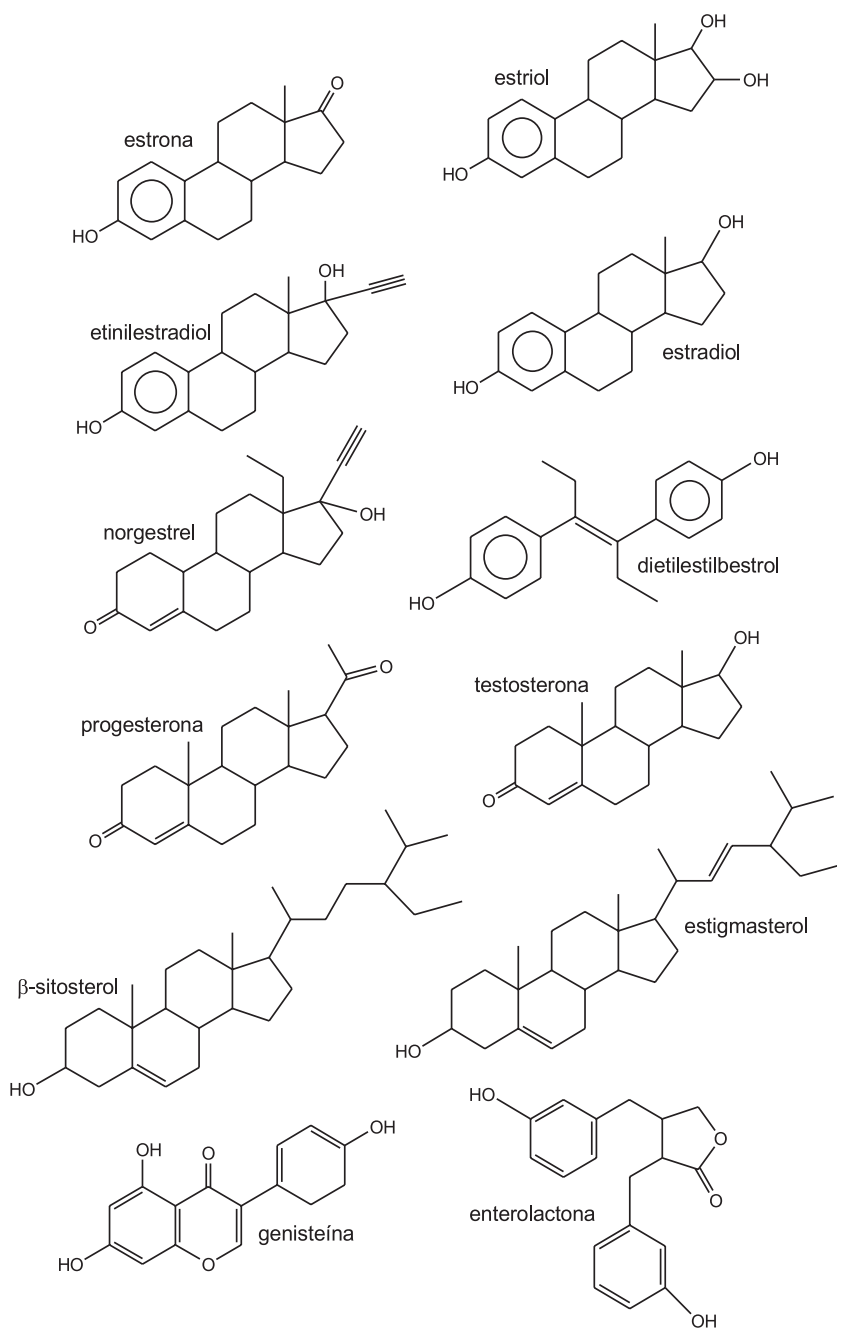

Figura 3. Estruturas químicas dos principais esteróides sexuais e fitoesteróides

\section{Fitoestrogênios}

Os fitoestrogênios são substâncias químicas naturais contidas nas plantas, que possuem atividade estrogênica e que atuam como constituintes das membranas celulares, como hormônios de crescimento, como antioxidantes (proteção contra as radiações UV), fungicidas, e algumas vezes como herbicidas. Estes fitoquímicos não nutricionais somam mais de 12.000 substâncias químicas naturais presentes nos alimentos de origem vegetal. Diferentemente dos hormônios sexuais, os fitoestrogênios são substâncias não 
Tabela 2. Propriedades físico-químicas e toxicidade aguda dos interferentes endócrinos abordados

\begin{tabular}{|c|c|c|c|c|c|c|c|}
\hline \multirow[t]{2}{*}{ Substância } & \multirow{2}{*}{$\begin{array}{c}\text { CAS } \\
\text { Number }\end{array}$} & \multirow{2}{*}{$\begin{array}{l}\text { Fórmula } \\
\text { Molecular }\end{array}$} & \multirow{2}{*}{$\begin{array}{c}\text { Massa } \\
\text { Molecular }(\mathrm{g} / \mathrm{mol})\end{array}$} & \multirow{2}{*}{$\begin{array}{c}\text { Solubilidade } \\
\mu \mathrm{g} / \mathrm{L} \mathrm{H}_{2} \mathrm{O}\left(25^{\circ} \mathrm{C}\right)\end{array}$} & \multirow[t]{2}{*}{$\log P_{o w}$} & \multicolumn{2}{|c|}{$\mathrm{LD}_{50}(\mathrm{mg} / \mathrm{kg}) *$} \\
\hline & & & & & & Macho & Fêmea \\
\hline Estrona & $53-16-7$ & $\mathrm{C}_{18} \mathrm{H}_{22} \mathrm{O}_{2}$ & 270,37 & 12.420 & 3,13 & & \\
\hline Estriol & $50-27-1$ & $\mathrm{C}_{18} \mathrm{H}_{24} \mathrm{O}_{3}$ & 288,39 & 13.250 & 2,45 & & \\
\hline Estradiol & $50-28-2$ & $\mathrm{C}_{18}^{18} \mathrm{H}_{24}^{24} \mathrm{O}_{2}$ & 272,39 & 12.960 & 4,01 & & \\
\hline Etinilestradiol & $57-63-6$ & $\mathrm{C}_{20} \mathrm{H}_{24} \mathrm{O}_{2}$ & 296,41 & 483 & 3,67 & 1737 & 1737 \\
\hline Progesterona & $57-83-0$ & $\mathrm{C}_{21} \mathrm{H}_{30} \mathrm{O}_{2}$ & 314,47 & & & & \\
\hline Testosterona & $58-22-0$ & $\mathrm{C}_{19} \mathrm{H}_{28} \mathrm{O}_{2}^{2}$ & 288,43 & 5.570 & 3,32 & & \\
\hline Norgestrel & $797-63-7$ & $\mathrm{C}_{21} \mathrm{H}_{28} \mathrm{O}_{2}^{2}$ & 312,44 & & & & \\
\hline Dietilestilbestrol & $56-53-1$ & $\mathrm{C}_{18}^{21} \mathrm{H}_{20}^{28} \mathrm{O}_{2}^{2}$ & 268,34 & & 5,07 & & \\
\hline Androsterona & $53-41-8$ & $\mathrm{C}_{19} \mathrm{H}_{30} \mathrm{O}_{2}$ & 290,43 & 8.750 & 3,69 & & \\
\hline$\beta$-Sitosterol & $83-46-5$ & $\mathrm{C}_{29} \mathrm{H}_{50} \mathrm{O}$ & 414,70 & & & & \\
\hline Estigmasterol & $83-48-7$ & $\mathrm{C}_{29}^{29} \mathrm{H}_{48} \mathrm{O}$ & 412,70 & & & & \\
\hline Genisteina & $446-72-0$ & $\mathrm{C}_{15} \mathrm{H}_{10} \mathrm{O}_{5}$ & 270,24 & & & & \\
\hline$p, p^{\prime}-\mathrm{DDT}$ & $50-29-3$ & $\mathrm{C}_{14} \mathrm{H}_{9} \mathrm{Cl}_{5}^{3}$ & 354,49 & 3,4 & 6,20 & 113 & 118 \\
\hline$p, p^{\prime}-\mathrm{DDE}$ & $72-55-9$ & $\mathrm{C}_{14} \mathrm{H}_{8} \mathrm{Cl}_{4}$ & 318,03 & 24 & 5,76 & 880 & 1240 \\
\hline$p, p$ '-DDD & $72-54-8$ & $\mathrm{C}_{14} \mathrm{H}_{10}^{0} \mathrm{Cl}_{4}^{4}$ & 320,05 & 90 & 5,86 & $>4000$ & \\
\hline Aldrin & $309-00-2$ & $\mathrm{C}_{12} \mathrm{H}_{8} \mathrm{Cl}_{6}$ & 364,91 & 27 & $5,17-7,40$ & 39 & 60 \\
\hline Dieldrin & $60-57-1$ & $\mathrm{C}_{12} \mathrm{H}_{8} \mathrm{Cl}_{6} \mathrm{O}$ & 380,91 & 140 & $3,69-6,20$ & 46 & 46 \\
\hline Endrin & $72-20-8$ & $\mathrm{C}_{12}^{12} \mathrm{H}_{8}^{0} \mathrm{Cl}_{6}^{0} \mathrm{O}$ & 380,91 & $220-260$ & $3,21-5,34$ & 18 & 7,5 \\
\hline Lindano & $58-89-9$ & $\mathrm{C}_{6} \mathrm{H}_{6}^{\circ} \mathrm{Cl}_{6}$ & 290,85 & 7.000 & 3,80 & & 88,9 \\
\hline Endossulfan & $115-29-7$ & $\mathrm{C}_{9} \mathrm{H}_{6} \mathrm{Cl}_{6} \mathrm{O}_{3} \mathrm{~S}$ & 406,95 & 320 & $2,23-3,62$ & & 43,2 \\
\hline Heptacloro & $76-44-8$ & $\mathrm{C}_{10} \mathrm{H}_{5} \mathrm{Cl}_{7}$ & 373,35 & 180 & $4,40-5,50$ & & 100 \\
\hline Metoxicloro & $72-43-5$ & $\mathrm{C}_{16} \mathrm{H}_{15} \mathrm{Cl}_{3} \mathrm{O}_{2}$ & 345,65 & 45 & $4,68-5,08$ & 5000 & 5000 \\
\hline Linuron & $330-55-2$ & $\mathrm{C}_{9} \mathrm{H}_{10} \mathrm{Cl}_{2} \mathrm{~N}_{2} \mathrm{O}_{2}$ & 249,11 & 75.000 & 3,20 & 1500 & 1500 \\
\hline Diuron & $330-54-1$ & $\mathrm{C}_{9} \mathrm{H}_{10} \mathrm{Cl}_{2} \mathrm{~N}_{2} \mathrm{O}$ & 233,10 & 42.000 & 2,68 & 437 & 437 \\
\hline Vinclozolina & $50471-44-8$ & $\mathrm{C}_{12} \mathrm{H}_{9} \mathrm{Cl}_{2} \mathrm{NO}_{3}$ & 286,11 & 3.400 & 3,10 & 10.000 & 10.000 \\
\hline Malation & $121-75-5$ & $\mathrm{C}_{10} \mathrm{H}_{19} \mathrm{O}_{6} \mathrm{PS}_{2}$ & 330,36 & 145.000 & & 1375 & 1000 \\
\hline Carbaril & $63-25-2$ & $\mathrm{C}_{12} \mathrm{H}_{11} \mathrm{NO}_{2}$ & 201,22 & 82.600 & & 250 & 250 \\
\hline Tributilestanho & $56573-85-4$ & $\mathrm{C}_{12} \mathrm{H}_{28} \mathrm{Sn}^{2}$ & 291,04 & $8.000-10.000$ & 3,62 & & \\
\hline Pentaclorofenol & 87-86-5 & $\mathrm{C}_{6} \mathrm{HCl}_{5} \mathrm{O}$ & 266,34 & 14.000 & $3,32-5,86$ & 146 & 175 \\
\hline PCB & $1336-36-3$ & $\mathrm{C}_{12} \mathrm{H}_{10-\mathrm{n}} \mathrm{Cl}_{\mathrm{n}}$ & vários & $0,1-6.000$ & $4,50-8,26$ & 1300 & 1300 \\
\hline Decabromodifeniléter & $1163-19-5$ & $\mathrm{C}_{12} \mathrm{Br}_{10} \mathrm{O}$ & 959,17 & & & & \\
\hline $2,3,7,8-\mathrm{TCDD}$ & $1746-01-6$ & $\mathrm{C}_{12} \mathrm{H}_{4} \mathrm{Cl}_{4} \mathrm{O}_{2}$ & 321,97 & 0,0013 & 6,76 & 0,022 & 0,045 \\
\hline 2,3,7,8-TCDF & $51207-31-9$ & $\mathrm{C}_{12} \mathrm{H}_{4} \mathrm{Cl}_{4}^{4} \mathrm{O}$ & 305,98 & 0,42 & 6,22 & & \\
\hline Bisfenol A & 80-05-7 & $\mathrm{C}_{15} \mathrm{H}_{16}^{4} \mathrm{O}_{2}$ & 228,29 & 120.000 & 3,40 & & \\
\hline Dibutilftalato & $84-74-2$ & $\mathrm{C}_{16} \mathrm{H}_{22} \mathrm{O}_{4}$ & 278,35 & 13.000 & & $>8000$ & $>8000$ \\
\hline Dietilftalato & $84-66-2$ & $\mathrm{C}_{12} \mathrm{H}_{14} \mathrm{O}_{4}$ & 222,24 & 400.000 & & $5,1 \mathrm{~mL}$ & $5,1 \mathrm{~mL}$ \\
\hline 4-Nonilfenol & $104-40-5$ & $\mathrm{C}_{15} \mathrm{H}_{24} \mathrm{O}$ & 220,35 & 5.430 & $4,48-5,99$ & & \\
\hline Octilfenóis & 27193-28-8 & $\mathrm{C}_{14} \mathrm{H}_{22} \mathrm{O}$ & 206,33 & 12.600 & 3,90 & & \\
\hline Naftaleno & 91-20-3 & $\mathrm{C}_{10} \mathrm{H}_{8}$ & 128,16 & 31.000 & & 490 & \\
\hline Fluoranteno & $206-44-0$ & $\mathrm{C}_{16} \mathrm{H}_{10}^{\circ}$ & 202,26 & 220 & 5,13 & & \\
\hline Antraceno & $120-12-7$ & $\mathrm{C}_{14} \mathrm{H}_{10}$ & 178,22 & 43,4 & & 18.000 & \\
\hline Benzo[a]pireno & $50-32-8$ & $\mathrm{C}_{20} \mathrm{H}_{12}$ & 252,30 & 3,3 & 6,13 & & \\
\hline
\end{tabular}

* $\mathrm{LD}_{50}$ : dose letal para 50\% das espécies estudadas (ratos ou camundongos), por via oral.

esteroidais que apresentam uma estrutura do tipo 2-fenilnaftaleno. Estes compostos fenólicos pertencem, basicamente, à família dos flavonóides e das ligninas ${ }^{2-4,21,53}$.

Durante o metabolismo secundário das plantas vários ácidos hidroxibenzóico e hidroxicinâmico são formados, sendo que suas concentrações variam de acordo com a planta em questão ${ }^{53}$. Podese encontrar várias classes de flavonóides, de acordo com o nível de oxidação e o modelo de substituição da cadeia heterocíclica. As principais classes de flavonóides são: flavonas, flavonóis, flavanonas, antocianidinas, isoflavonas e chalconas ${ }^{3,4,53}$.

Vários cientistas têm focado suas pesquisas nas isoflavonas e nas ligninas. As isoflavonas são encontradas em uma variedade de plantas, incluindo as frutas, legumes e vegetais e são especialmente abundantes na soja e seus derivados, enquanto que as ligninas são produzidas a partir do catabolismo biológico de grãos inteiros, sementes, fibras e algumas frutas e vegetais, apresentando altas concentrações nas sementes do linho. As estruturas da genisteina (isoflavona) e enterolactona (lignina) são mostradas na Figura 3. As isoflavonas possuem uma estrutura difenólica que se assemelha aos estrogênios sintéticos como o dietilestilbestrol (DES). Já as ligninas possuem uma estrutura derivada do 2,3-dibenzilbutano ${ }^{2-4,21,53}$.

Ambos os tipos de fitoestrogênios têm apresentado uma atividade estrogênica da ordem de $10^{-2}$ a $10^{-3}$ quando comparada ao $17 \beta$ estradiol $^{3}$. Isto significa que, se um fitoestrogênio se ligar no organismo a um receptor de estrogênio, irá produzir uma resposta cerca de 100 a 1000 vezes menor que a de um estrogênio endógeno. Embora a concentração destas substâncias no corpo humano possa ser até 100 vezes maior que os valores encontrados para os estrogênios 
endógenos, elas são facilmente metabolizadas e excretadas pela urina e pela bílis, na forma de glucoronídios e sulfatos conjugados. Portanto, a inclusão destas substâncias na dieta humana tem conferido mais um efeito benéfico à saúde que deletério. Afinal, evidências científicas têm mostrado que os fitoestrogênios podem apresentar alguns benefícios à saúde quando relacionados a doenças cardiovasculares, câncer, osteoporose e sintomas da menopausa ${ }^{2-4,21,53}$.

Por outro lado, estudos realizados com animais provenientes de regiões agrícolas (monocultura) demonstraram que alguns fitoestrogênios apresentaram atividade estrogênica com efeitos deletérios à saúde animal. Algumas ovelhas, após terem sido alimentadas por longo período com um tipo especial de pasto que continha as isoflavonas genisteina, formonoetina e biochanina A desenvolveram sintomas de infertilidade ${ }^{56}$. Posteriormente, estudos envolvendo ensaios in vivo com ratos e camundongos fêmeas ovariectomizadas comprovaram tal potencial estrogênico ${ }^{57}$. Ensaios in vitro mais recentes também mostraram que muitos fitoestrogênios se ligam aos receptores de estrogênios, produzindo um efeito agonista similar aos esteróides sexuais exógenos ${ }^{58}$. Uma vez que a exposição ambiental às isoflavonas tem sido negligenciada pelos pesquisadores, poucos dados científicos são encontrados na literatura ${ }^{4}$.

Outras duas importantes substâncias naturais que exibem atividade estrogênica são a zearalenona, uma micotoxina produzida por um fungo presente nos alimentos embolorados, como milho, algodão e cevada, e o $\beta$-sitosterol, encontrado em óleos vegetais, legumes e na madeira. O $\beta$-sitosterol é usado como um moderador lipídico em medicamentos, podendo também ser detectado, em elevadas concentrações, nos efluentes provenientes de industrias de óleo, polpa e papel ${ }^{4}$.

Vários testes e biomarcadores têm sido desenvolvidos para detectar a atividade estrogênica de uma determinada substância. Um marcador bastante usado é a vitelogenina (VTG), uma proteína presente no plasma sangüíneo e que desempenha importante papel no sistema reprodutivo de vertebrados ovíparos fêmeas. Tal substância, sintetizada no fígado, é regulada por estrogênios e transportada através do sangue para os ovários. Em organismos de machos a vitelogenina também está presente, mas apresenta uma concentração pouco expressiva. Entretanto, sua concentração no plasma pode se tornar elevada após a exposição de um determinado organismo a substâncias que apresentam atividade estrogênica ${ }^{4,5,18,22,57}$. É o caso do $\beta$-sitosterol, capaz de induzir a produção de vitelogenina em peixes machos, bem como produzir efeitos androgênicos em peixes fêmeas, tais como o desenvolvimento dos órgãos reprodutivos masculinos ${ }^{59}$.

\section{Substâncias químicas sintéticas}

Esta classe de substância suspeita de causar alteração no sistema endócrino é composta pelas substâncias de origem antrópica como os xenoestrogênios (também denominados estrogênios ambientais) e aquelas comumente utilizadas como matéria-prima ou fabricadas durante os processos industriais. Também fazem parte desta classe as substâncias usadas nas atividades agrícolas, como os pesticidas ${ }^{2-5,22,40,44-46,48-51,60-64}$.

Os produtos químicos sintéticos e os estrogênios ambientais incluem uma série de organoalogenados persistentes como os inseticidas DDT e seu metabólito DDE, toxafeno, dieldrin, bifenilas, assim como uma variedade de outros compostos não organoclorados como os bifenóis, ftalatos, alquilfenóis, hidrocarbonetos policíclicos aromáticos, compostos organometálicos, dentre outros ${ }^{2}$.

Os pesticidas compreendem um grupo de substâncias produzidas com o objetivo de eliminar um organismo indesejável ou controlá-lo de alguma maneira, por exemplo, interferindo em seu processo reprodutivo. Todos os pesticidas têm a propriedade comum de bloquear um processo metabólico vital dos organismos para os quais são tóxicos. Devido à grande diversidade de produtos existentes (somente no Brasil são cerca de 300 princípios ativos em 2 mil formulações comerciais diferentes), os pesticidas podem ser classificados de acordo com sua função, como por ex., inseticidas, herbicidas, fungicidas, algicidas, dentre outros, e também de acordo com o seu poder tóxico. Esta segunda classificação é fundamental para o conhecimento da toxicidade aguda de um determinado pesticida ${ }^{2,61}$.

Vários pesticidas, bem como muitos de seus metabólitos, estão comprovadamente relacionados com alterações no sistema endócrino, observadas em estudos envolvendo ensaios in vitro e in vivo, sobretudo de espécies animais provenientes de ambientes aquáticos. Muitos deles também são persistentes no meio ambiente devido, principalmente, a sua estabilidade química, baixa solubilidade em água e elevada lipofilicidade, podendo ser facilmente bioacumulados. Dentre as substâncias, destacamse os inseticidas organoclorados como os ciclodienos (aldrin, dieldrin, endrin, clordano, toxafeno, telodrin, isodrin, endossulfan, heptacloro e mirex), os diclorodifeniletanos e seus derivados (DDT e metabólitos DDE e DDD, bem como o metoxicloro), e os hexaclorocicloexanos (isômeros do hexaclorobenzeno - $\mathrm{HCH}$, sendo o lindano, ou $\gamma-\mathrm{HCH}$, o mais importante deles); os inseticidas à base de organofosforados e carbamatos (diclorvos, clorpirifos, paration, diazinon, carbaril e carbofurano); os fungicidas como a vinclozolina (usada em frutas e vegetais e cujos metabólitos apresentam atividades anti-androgênicas); os herbicidas (à base de triazinas, como atrazina e simazina, e linuron, diuron e seus metabólitos) e, ainda, os pesticidas organometálicos, como o tributilestanho (TBT), empregado como moluscicida, fungicida (preservante de madeira), biocida e inseticida, bem como estabilisante de plásticos à base de PVC, e ainda usado pela Marinha como agente "antimofo" (algicida) nas tintas aplicadas em embarcadouros, cascos de navios, recipientes para conserva de lagostas, redes de pesca, etc., com o objetivo de evitar incrustações e prevenir o acúmulo de organismos marinhos viscosos, como larvas de bálanos ${ }^{2-5,22,48-50,61}$.

O pentaclorofenol também é utilizado como pesticida com múltiplos usos: herbicida como desfolhante pré-colheita, inseticida no controle de cupins, fungicida como preservante de madeira e no tratamento de sementes, e como moluscicida no controle de lesmas. O interesse ambiental envolvendo tal substância está na sua elevada toxicidade, uma vez que é considerada como sendo uma das maiores fontes de geração de dioxinas para o ambiente, por ex., após a queima da madeira tratada com pentaclorofenol ${ }^{2,22}$.

As bifenilas constituem um grupo de produtos químicos sintéticos caracterizados pela presença de anéis aromáticos halogenados. As bifenilas policloradas (PCB) foram introduzidas no meio ambiente em 1929 e produzidas por vários países a partir de diversos processos industriais. Teoricamente esta classe compreende 209 compostos individuais (congêneres), mas apenas 130 deles são encontrados em produtos comerciais. Embora a produção destes compostos tenha sido banida em 1980, suas aplicações incluem o uso em capacitores dielétricos, fluidos hidráulicos, lubrificantes, fluidos de transferência de calor e plastificantes. Tais compostos são encontrados nos ambientes aquáticos principalmente adsorvidos nos sedimentos e/ou materiais particulados, devido à elevada bioestabilidade, hidrofobicidade e lipofilicidade, e seu potencial para bioacumulação e biomagnificação. Em vista de sua toxicidade e a de seus contaminantes (furanos), as bifenilas policloradas presentes no ambiente, bem como os seus metabólitos como as PCB hidroxiladas, são bastante impactantes à saúde humana e animal, particularmente no que se refere ao crescimento e desenvolvimento de um determinado organismo, podendo exibir efeitos agonista e antagonista no sistema endócrino. Portanto, a principal fonte de exposição humana às bifenilas policloradas está nos alimentos, principalmente no consumo de peixes e derivados, e animais com altos teores de gorduras ${ }^{2-4,22,48-50,64}$. 
As bifenilas polibromadas (PBB) são empregadas como aditivos nas formulações de materiais usados como agentes retardantes de chama, no combate a incêndios. Tais agentes são usados em plásticos, circuitos eletrônicos, pela indústria têxtil e em outros materiais empregados para prevenir incêndios. Além das PBB (dos 209 possíveis congêneres apenas 45 destes foram sintetizados), outras substâncias como os difeniléteres polibromados (PBDE), o hexabromociclododecano (HBCD) e o tetrabromobisfenol A (TBBPA) também são comumente utilizados como agentes retardantes de chama. Estas substâncias são empregadas mundialmente em vastas quantidades. Estima-se que $600 \mathrm{mil} \mathrm{t}$ de retardantes de chama são produzidas mundialmente, a cada ano, sendo 60 mil correspondente aos compostos clorados e $150 \mathrm{mil}$ aos compostos bromados. Estas substâncias são bastante persistentes, lipofílicas e apresentam elevado potencial para bioacumulação. Também mostraram produzir uma resposta estrogênica em estudos envolvendo ensaios in vitro $^{3,5,22}$

As dioxinas e furanos são denominações genéricas para dois grupos similares de substâncias químicas aromáticas e policloradas: as dibenzo-p-dioxinas (PCDD) e os dibenzofuranos (PCDF). Estas substâncias não são produzidas comercialmente e sim geradas como subprodutos de vários processos industriais e de combustão. Sem dúvida, a principal fonte destas substâncias é a incineração de resíduos (lixo), como os provenientes de áreas hospitalares e municipais ${ }^{2-4,22,48,49}$.

Dioxinas e furanos são formadas na zona de pós-combustão dos incineradores, onde a temperatura é muito menor (250-500 ${ }^{\circ} \mathrm{C}$ ) que a da própria chama. Traços de íons metálicos contidos no resíduo provavelmente catalisam o processo de combustão, sendo a quantidade de cloro presente no lixo mais que suficiente para formação das mesmas. Chamas provenientes de incêndios florestais também emitem para o ambiente vários congêneres da família das dioxinas. Outras fontes incluem a reciclagem de metais e a produção de solventes comuns, e as indústrias de polpa e papel que ainda empregam processos de branqueamento da polpa de celulose à base de cloro $^{2-4}$. A tetraclorodibenzo- $p$-dioxina (TCDD) é a substância mais biologicamente ativa e mais tóxica das presentes neste grupo de contaminantes ambientais. Estudos com animais mostraram que a TCDD apresenta um efeito deletério nas funções reprodutivas, produzindo ambos os efeitos anti-estrogênico e antiandrogênico. Dioxinas e furanos também são persistentes no meio ambiente e podem ser bioacumuladas nos organismos, causando alterações no sistema endócrino, uma vez que são substâncias comprovadamente cancerígenas ${ }^{2-4,22,48,49}$.

Bisfenol é um nome genérico dado a um grupo de difenilalcanos comumente empregados na produção de plásticos. O bisfenol A, principal representante deste grupo, é uma substância amplamente utilizada durante os processos industriais como monômero na produção de polímeros, policarbonatos, resinas epóxi e resinas de poliésterestireno insaturadas, e ainda como fungicidas e agentes retardantes de chama. Outras aplicações incluem seu uso como estabilizante na produção de plásticos (inclusive embalagens de alimentos), como revestimento interno nas latas de alumínio usadas em bebidas, como selante dentário, como antioxidante, dentre outras. Este composto ocorre no ambiente como resultado do processo de lixiviação dos produtos finais manufaturados a partir deste, podendo estar presente nos vários compartimentos: ar, água, solo, sedimento e biota. Embora apresente solubilidade em água moderadamente elevada, o valor do seu coeficiente de partição octanol-água $\left(\log K_{o w} 3,4\right)$ permite assumir que tal substância está preponderantemente adsorvida na matéria orgânica. Entretanto, seu transporte no ambiente aquático constitui a maior rota de distribuição para os demais compartimentos ambientais. Uma vez presente no meio ambiente, o bisfenol A pode vir a ser degradado biologicamente, com velocidades bastante diferenciadas, apresentando um tempo de meia-vida variando entre 1 a 180 dias em solos, bem como um tempo de meia-vida de 2,5 a 4 dias quando em água. Com relação à sua atividade estrogênica, alguns estudos envolvendo ensaios in vitro mostram que o bisfenol A possui um potencial de 4 a 6 ordens de magnitude menor que o $17 \beta$ estradiol e, ainda, que pode apresentar atividade anti-androgênica. Pelo fato do bisfenol A ser bastante empregado nos processos industriais e também por participar das formulações de produtos de uso doméstico, suas principais fontes no meio ambiente são os efluentes industriais, os esgotos domésticos, bem como os lodos provenientes das estações de tratamento de esgoto (ETE) ${ }^{2-4,22,44,45}$.

Os diésteres derivados do ácido ftálico são empregados basicamente como plastificantes, principalmente aqueles contendo o grupo vinil como o cloreto de polivinila (PVC) e outras resinas como acetato de polivinila e poliuretano, bem como na fabricação de tintas, adesivos, papelão, lubrificantes e fragrâncias, e têm sido utilizados há mais de 40 anos. Ftalatos podem ser introduzidos no ambiente através da lixiviação, sobretudo dos plastificantes utilizados na fabricação de plásticos de uso comum. Tais ftalados são encontrados não apenas na água lixiviada como também nos lodos provenientes dos esgotos, na água superficial, no sedimento e em algumas espécies aquáticas, inclusive peixes. Por serem lipofílicos tendem a se acumular nos tecidos adiposos das espécies envolvidas em uma determinada cadeia alimentar, em um processo conhecido como biomagnificação. Como os seres humanos são muitas vezes o topo desta cadeia alimentar, altas concentrações destas substâncias poderão estar presentes na sua dieta. Em geral, a toxicidade aguda destes compostos é relativamente baixa. Porém, estudos ecotoxicológicos têm mostrado que alguns produtos da degradação destes, como os monoésteres, podem ser tóxicos para os mamíferos ${ }^{2,3,22,44,62,63}$.

Os alquilfenóis compreendem os surfactantes não iônicos empregados principalmente na forma de etoxilados e que são sintetizados através da adição de óxido de etileno ao nonilfenol, sob condições alcalinas. Dentre os alquilfenóis, 4-nonilfenol e 4-octilfenol são os compostos de maior importância ambiental devido à escala em que são produzidos no ambiente, a partir de processos de biodegradação dos alquilfenóis etoxilados. Embora nos últimos anos o uso destes compostos na formulação de detergentes de uso doméstico tenha sido diminuído em alguns países da Europa, eles ainda continuam sendo empregados como componentes de detergentes industriais, como agentes dispersantes na produção de polpa e papel, como agentes emulsificantes nas formulações de tintas látex e pesticidas, como aditivos plásticos na produção de resinas fenólicas, como agente floculante, como espermicida em aplicações contraceptivas, nas indústrias têxteis, dentre outras. A maioria destes etoxilados, durante os processos de biodegradação como os empregados nas ETE, geram subprodutos tóxicos e persistentes que, após serem introduzidos no meio ambiente, são acumulados nos organismos aquáticos uma vez que são mais lipofílicos que os compostos que os originaram ${ }^{2-4,22,45,46}$.

Os hidrocarbonetos policíclicos aromáticos (PAH) compreendem um grupo de mais de 100 substâncias químicas formadas principalmente durante a combustão incompleta da matéria orgânica, tais como combustíveis derivados do petróleo (gasolina e óleo diesel) ou ainda a partir do carvão, madeira, etc. São formados a partir de fontes naturais ou antrópicas, sendo esta última a principal responsável pela presença destes contaminantes no meio ambiente. As fontes naturais ocorrem como conseqüência de processos de síntese por bactérias, plantas e fungos, além dos processos naturais de combustão, como os incêndios florestais e as emissões vulcânicas. Já as fontes antrópicas incluem os efluentes industriais e esgotos domésticos, processos de incineração de resíduos (inclusive lixos urbanos), derramamento acidental de petróleo, produção de asfalto e de alumínio e queima de combustíveis fósseis, princi- 
palmente provenientes de emissões veiculares ${ }^{2-4,22,50,64}$. Apresentam uma estrutura contendo dois ou mais anéis aromáticos fundidos, conforme ilustrado na Figura 4 para o benzo[a]pireno.

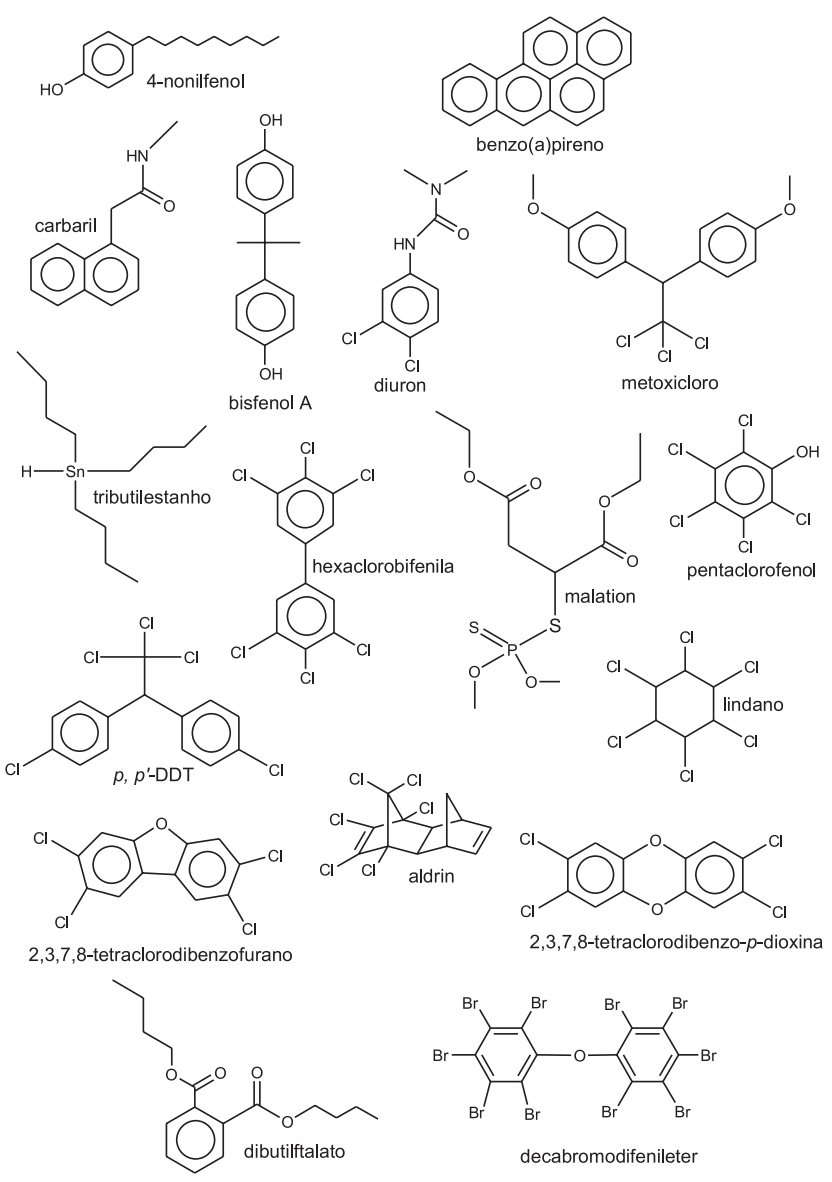

Figura 4. Fórmulas estruturais de algumas substâncias químicas sintéticas

A persistência dos hidrocarbonetos policíclicos aromáticos no ambiente varia de acordo com a massa molar. Os que apresentam baixa massa molar, como naftaleno e antraceno, são degradados mais facilmente, apresentando um tempo de meia-vida que varia entre 9 a 43 h. Entretanto, a maioria deles apresenta elevada lipofilicidade podendo ser facilmente bioacumulados no meio ambiente. Pelo fato de apresentarem estruturas similares aos esteróides sexuais podem também interferir no funcionamento natural do sistema endócrino, ligando-se aos receptores hormonais e produzindo um efeito antagonista, como já observado em estudos envolvendo ensaios biológicos in vitro e in vivo ${ }^{2-4,22,50,64}$

A Figura 4 ilustra as estruturas das principais substâncias químicas sintéticas mencionadas. As propriedades físico-químicas mais relevantes ${ }^{2-4,22,27,49,55,65}$ e a toxicidade aguda $\left(\mathrm{LD}_{50}\right)^{49,55}$ dos interferentes endócrinos abordados neste artigo são fornecidas na Tabela 2.

\section{CONCLUSÃO}

Embora alguns estudos científicos já terem relatado, há mais de 20 anos, a ocorrência no meio ambiente de algumas substâncias classificadas como interferentes endócrinos, somente nos últimos 10 anos é que pesquisas nesta área começaram a ser intensificadas, principalmente em países europeus, como Alemanha, Holanda, Suíça e Espanha, e também nos EUA, visando não apenas a determinação analítica dos mesmos nos mais variados compartimentos ambientais e a identificação de suas principais fontes, como também buscando desenvolver procedimentos analíticos que permitissem avaliar os mecanismos de ação destas substâncias no sistema endócrino de animais, incluindo os seres humanos.

Hormônios sexuais naturais e sintéticos são potentes interferentes endócrinos e podem ser encontrados nos ambientes aquáticos em concentrações fisiológicas, ou seja, muito próximas das encontradas no organismo. Entretanto, para se avaliar os riscos da exposição de organismos aquáticos a tais substâncias deve-se compreender também os mecanismos de degradação que as envolvem, além do monitoramento das suas concentrações no meio ambiente. Para isso, deve-se recorrer aos ensaios biológicos do tipo in vitro e/ou in vivo, embora este último forneça dados ecotoxicológicos mais relevantes quando se trata da identificação de interferentes endócrinos em potencial.

Para muitas substâncias químicas sintéticas como os pesticidas, os efeitos produzidos a partir das atividades dos mesmos no sistema endócrino (estrogênica, androgênica, anti-estrogênica e/ou antiandrogênica), observados em ensaios in vitro, apresentam ordens de magnitude menores quando comparados aos hormônios endógenos como o estradiol, conforme relatado por alguns pesquisadores. Porém, não se deve ignorar a presença dos mesmos no meio ambiente, pois, embora pareçam ser menos potentes que os hormônios endógenos, muitos deles (especialmente os POP) são persistentes no ambiente, acumulando-se nos vários compartimentos, principalmente biota, sendo posteriormente detectados nas águas, nos sedimentos, no material particulado rico em matéria orgânica, mesmo após terem deixado de ser produzidos industrialmente há várias décadas.

Os interferentes endócrinos apresentam uma variedade de rotas de exposição no meio ambiente, dependendo basicamente das suas propriedades físico-químicas inerentes, das condições externas em que são utilizados, das condições ambientais como temperatura, radiação UV e conteúdo microbiológico, dentre outros fatores.

Uma das principais razões para que haja uma preocupação sobre este tema está nos possíveis efeitos dos interferentes endócrinos na saúde humana e no meio ambiente, incluindo várias espécies animais. Substâncias químicas suspeitas de causar alteração no sistema endócrino estão potencialmente associadas a várias doenças, como o câncer de testículo, de mama e de próstata, à queda da taxa de espermatozóides, deformidades dos órgãos reprodutivos, disfunção da tireóide e alterações relacionadas com o sistema neurológico.

\section{AGRADECIMENTOS}

Esse projeto tem o apoio da FAPESP (Fundação de Amparo à Pesquisa do Estado de São Paulo), através dos processos 02/01829-4 (Doutorado), 01/02060-3 e 03/11757-3 (ambos Auxílio à Pesquisa).

\section{REFERÊNCIAS}

1. Bechara, E. J. H.; Quim. Nova 1992, 15, 117.

2. Baird, C.; Química Ambiental, 2 ${ }^{\mathrm{a}}$ ed., Bookman: Porto Alegre, 2002, cap. 6 e 7.

3. Birkett, J. W.; Lester, J. N.; Endocrine Disrupters in Wastewater and Sludge Treatment Processes, $1^{\text {st }}$ ed., IWA Publishing, Lewis Publishers CRC Press LLC: USA, 2003.

4. Lintelmann, J.; Katayama, A.; Kurihara, N.; Shore, L.; Wenzel, A.; Pure Appl. Chem. 2003, 75, 631.

5. Ankley, G.; Mihaich, E.; Stahl, R.; Tillitt, D.; Colborn, T.; Mcmaster, S.; Miller, R.; Bantle, J.; Campbell, P.; Denslow, N.; Dickerson, R.; Folmar, L.; Fry, M.; Giesy, J.; Gray, L.E.; Guiney, P.; Hutchinson, Th.; Kennedy, S.; Kramer, V.; LeBlanc, G.; Mayes, M.; Nimrod, A.; Patino, R.; Peterson, R.; Purdy, R.; Ringer, R.; Thomas, P.; Touart, L.; van der Kraak, G.; Zacharewski, T.; Environ. Toxicol .Chem. 1998, 17, 68.

6. Mccann, B.; Water 21 2004, April, IWA Publishing, 20; Mccann, B.; Water 21 2002, October, IWA Publishing, 45.

7. http://biology.usgs.gov/s+t/SNT/noframe/co117.htm, acessada em Janeiro 2002. 
8. Sumpter, J. P.; Johnson, A.C.; Environ. Sci. Technol. 2005, 39, 4321.

9. Comissão das Comunidades Européias; Relatório Final COM(1999)706, obtido na internet em Outubro 2001

10. Masters, B.; $W \& W I$. 2001, 16, 11 .

11. European Workshop on the Impact of Endocrine Disruptors on Human Health and Wildlife; Report of Proceedings, 2-4 December, Weybridge, U.K., 1996 apud ref. 4.

12. European Commission; Report No. EUR17549, 1996 apud ref. 3.

13. http://www.epa.gov/opptintr/opptindo/finalrept/htm, acessada em Abril 2005.

14. EPA; Special Report No. EPA/630/R-96/012, Washington D.C., 1997, 111 apud ref.3.

15. UK Economics Account; Environment Agency, United Kingdom, 2000, 23 apud ref. 3.

16. Phillips, B.; Harrison, P.; Overview in Endocrine Disrupting Chemicals, The Royal Society of Chemistry, Cambridge, 1999, 1 apud ref. 3.

17. Hughes, C.; J. Clin. Endocrinol. Metab. 1996, 81, 2405 apud ref. 3.

18. Bila, D. M.; Dezotti, M.; Quim. Nova 2003, 26, 523.

19. Silva, C. A.; Pereira, E. A.; Tavares, M. F. M.; Resumos da $28^{a}$. Reunião Anual da Sociedade Brasileira de Química, Poços de Caldas, Brasil, 2005.

20. Ghiselli, G.; Jardim, W. F.; Resumos da $28^{a}$. Reunião Anual da Sociedade Brasileira de Química, Poços de Caldas, Brasil, 2005; Ghiselli, G.; Jardim, W. F.; Relatórios Fapesp 2003, 2004 e 2005.

21. Shimada, K.; Mitamura, K.; Higashi, T.; J. Chromatogr., A 2001, 935, 141.

22. Hoffman, D. J.; Rattner, B. A.; Burton Jr., G. A.; Cairns Jr., J.; Handbook of Ecotoxicology, $2^{\text {nd }}$ ed., Lewis Publishers CRC Press LLC: USA, 2003, section V, cap. 39.

23. López de Alda, M. J.; Barceló, D.; Fresenius J. Anal. Chem. 2001, 371, 437.

24. Bevan, C. L.; Prasad, A.; Henderson, L. P.; Relatório, obtido na internet em Outubro 2001.

25. http://www.ourstolenfuture.org/basics/chemlist.htm, acessada em Outubro 2001.

26. http://www.wwfcanada.org/hormone-disruptors/list.htm, acessada em Outubro 2001

27. http://www.iarc.fr, acessada em Setembro 2003.

28. Ghiselli, G.; Palestra apresentada na I Escola de Química Ambiental do IQ-Unicamp, Campinas, Brasil, 2004.

29. Manahan, S. E.; Fundamentals of Environmental Chemistry, $2^{\text {nd }}$ ed., Lewis Publishers CRC Press LLC: USA, 2001; Manahan, S. E.; Environmental Chemistry, $7^{\text {th }}$ ed., CRC Press LLC: USA, 2000.

30. Almeida, F. V.; Palestra apresentada na I Escola de Química Ambiental do IQ-Unicamp, Campinas, Brasil, 2004.

31. Mozeto, A. A.; Palestra apresentada na I Escola de Química Ambiental do IQ-Unicamp, Campinas, Brasil, 2004.

32. Oga, S.; Fundamentos de Toxicologia, 1ª ed., Atheneu Editora: São Paulo, 1996.

33. Ternes, T. A.; Water Res. 1998, 32, 3245.

34. Ternes, T. A.; Stumpf, M.; Mueller, J.; Haberer, K.; Wilken, R.-D.; Servos, M.; Sci. Total Environ. 1999, 225, 81.

35. Hirsch, R.; Ternes, T.; Haberer, K.; Kratz, K. L.; Sci. Total Environ. 1999, $225,109$.
36. Heberer, T.; Schmidt-Bäumler, K.; Stan, H. J.; Acta Hydrochim. Hydrobiol. 1998, 26, 272

37. Stan, H. J.; Heberer, T.; Analusis Mag. 1997, 25, 20.

38. Halling-Sørensen, B.; Nielsen, S. N.; Lanzky, P. F.; Ingerslev, F.; HoltenLützhøft, H. C.; Jørgensen, S. E.; Chemosphere 1998, 36, 357

39. Kümmerer, K.; Chemosphere 2001, 45, 957.

40. Kolpin, D. W.; Furlong, E. T.; Meyer, M.T.; Thurman, E. M.; Zaugg, S. D.; Barber, L. B.; Buxton, H. T.; Environ. Sci. Technol. 2002, 36, 1202.

41. Belfroid, A. C.; van Der Horst, A.; Vethaak, A. D.; Schäfer, A. J.; Rijs, G. B. J.; Wegener, J.; Cofino, W. P.; Sci. Total Environ. 1999, 225, 101.

42. Daughton, C. G.; J. Am. Soc. Mass Spectrom. 2001, 12, 1067.

43. Jones, O. A. H.; Voulvoulis, N.; Lester, J. N.; Water Res. 2002, 36, 5013.

44. Fromme, H.; Küchler, T.; Otto, T.; Pilz, K.; Müller, J.; Wenzel, A.; Water Res. 2002, 36, 1429.

45. Heemken, O. P.; Reincke, H.; Stachel, B.; Theobald, N.; Chemosphere 2001, 45, 245.

46. Guenther, K.; Heinke, V.; Thiele, B.; Kleist, E.; Prast, H.; Raecker, T.; Environ. Sci. Technol. 2002, 36, 1676.

47. Duguet, J-P.; Bruchet, A.; Mallevialle, J.; IWA Yearbook 2004, p. 41.

48. Barra, R.; Colombo, J. C.; Eguren, G.; Gamboa, N.; Jardim, W. F.; Mendoza, G.; Environ. Contam. Toxicol. 2005, 185, 1.

49. UNEP Chemicals; Global Report 2003; UNEP Chemicals; Eastern and Western South America Regional Report 2002, disponíveis em http:// www.chem.unep.ch/pts.

50. Almeida, F. V.; Tese de Doutorado, Universidade Estadual de Campinas, Brasil, 2003.

51. Bisinoti, M. C.; Jardim,W. F.; Quim. Nova 2004, 27, 593.

52. López de Alda, M. J.; Barceló, D.; J. Chromatogr., A 2000, 892, 391.

53. Prado, M. A.; trabalho não publicado.

54. Shore, L. S.; Gurevich, M.; Shemesh, M.; Bull. Environ. Contam. Toxicol. 1993, 51, 361 apud ref. 4

55. Chapman \& Hall; The Merck Index, Version 12:2 [Cd-Rom], New York, 1997 56. Adams, N. R.; Pure Appl. Chem. 1998, 70, 1855 apud ref. 4

57. Medlock, K. L.; Branham, W. S.; Sheehan, D. M.; Proc. Soc. Exp. Biol. Med. 1995, 208, 307 apud ref. 4.

58. Miksicek, R. J.; Proc. Soc. Exp. Biol. Med. 1995, 30, 212 apud ref. 4.

59. Stahlschmidt-Allner, P.; Allner, B.; Römbke, J.; Knacker, T.; Environ. Sci. Pollut. Res. 1997, 4, 155 apud ref. 4.

60. López de Alda, M. J.; Díaz-Cruz, S.; Petrovic, M.; Barceló, D.; J. Chromatogr., A 2003, 1000, 503.

61. Ghiselli, G.; Dissertação de Mestrado, Universidade Estadual de Campinas, Brasil, 2001.

62. Jonsson, S.; Ejlertsson, J.; Ledin, A.; Mersiowsky, I.; Svensson, B. O.; Water Res. 2003, 37, 609 .

63. Fatoki, O. S.; Noma, A.; Water, Air, Soil Pollut. 2002, 140, 85.

64. Silva, G. S.; Tese de Doutorado, Universidade Estadual de Campinas, Brasil, 2004.

65. http://chemfinder.cambridgesoft.com, acessada em Agosto 2005 